\title{
Culture of human dental pulp cells at variable times post-tooth extraction
}

\section{Daniela Ferreira Araújo BENÍCIO(a) Luciana Oliveira PEREIRA ${ }^{(b)}$ Izabel Cristina Rodrigues da SILVA ${ }^{(c)}$ Ricardo Bentes AZEVEDO(a) Ana Cristina Barreto BEZERRA ${ }^{(d)}$}

(a) Universidade de Brasília - UnB, Institute of Biological Sciences, Laboratory of Nanobiotechnology, Brasília, DF, Brazil.

(b) Regional Hospital of Taguatinga,

Taguatinga, DF, Brazil.

(c) Universidade de Brasília - UnB, Faculty of Ceilandia, Ceilândia, DF, Brazil.

(d) Universidade de Brasília - UnB, Department of Dentistry, Brasília, DF, Brazil

Declaration of Interests: The authors certify that they have no commercial or associative interest that represents a conflict of interest in connection with the manuscript.

\section{Corresponding Author:}

Daniela Ferreira Araúio Benício

E-mail: dentista.dani@gmail.com

https://doi.org/10.1590/1807-3107bor-2018.vol32.0003

Submitted: July 14, 2017

Accepted for publication: Nov 27, 2017

Last revision: Dec 12, 2017
Abstract: The aim of this study was to investigate the viability of human dental pulp cells from extracted teeth kept at standard room temperature and atmospheric pressure for different periods of time. Twenty-one healthy permanent teeth were used. They were divided into five groups according to the expected time from extraction to processing. One group was tested immediately after extraction; the other groups were each tested at one of the following time points: 30 minutes, 1 hour, 2 hours, and 5 hours post-extraction. Cell morphology was analysed by light microscopy; cell proliferation was analysed using MTT assay and by counting the viable cells in a haemocytometer. Similar results were observed in all groups ( $p$ 0.05). A delay of up to five hours for tooth processing and tissue collection does not preclude the establishment of dental pulp cell cultures, affect the morphology of these cells, or reduce their proliferative potential.

Keywords: Adult Stem Cells; Dental Pulp; Mesenchymal Stem Cell; Stem Cell Research

\section{Introduction}

Tooth as a source of autologous stem cells was a very significant discovery. Human dental pulp stem cells (hDPSCs) have the potential for infinite applications in reconstruction and regenerative therapies and tissue repair.

Human dental pulp stem cells are easily accessible and histocompatible. ${ }^{1}$ DPSCs with high proliferative capacities only demonstrated impaired differentiation following prolonged expansion. ${ }^{2}$ Moreover, there are no ethical or religious conflicts surrounding their use and research. Such conflicts are causing many scientists to choose to work with mesenchymal stem cells which are not derived from embryos. ${ }^{3}$

Dental pulp stem cells (DPSCs) have been differentiated ${ }^{4}$ into odontoblasts, ${ }^{5,6}$ osteoblasts; ${ }^{1}$ adipocytes, chondrocytes, and osteocytes; ${ }^{7,8}$ nerve cells; ${ }^{8}$ and hepatocytes. ${ }^{9}$ Furthermore, the combined use of tissue engineering and DPSCs has enabled the regeneration of a dentin-pulp complex ${ }_{1}^{10}$ the generation of functional roots, ${ }^{11}$ and even the production of a complete tooth. ${ }^{12}$

Dental pulp stem cells have survived and proliferated in a self-assembling peptide hydrogel that could conceptually be used in regenerative endodontics, allowing stem cell therapy inside the root canal. ${ }^{13}$ 
Besides that, DPSCs were effective in regenerating bone tissue, ${ }^{14,15,16}$ hair follicles, ${ }^{17}$ heart muscle, ${ }^{18,19}$ neuronal cells, ${ }^{20}$ and corneal epithelium. ${ }^{21}$ Furthermore, these stem cells are immunoprivileged and have the ability to modulate immune and inflammatory responses. ${ }^{22}$

Autologous DPSCs were successfully combined with buccal fat pad stromal vascular fraction to repair a mandibular defect caused by the resection of an ameloblastoma. ${ }^{23}$ Moreover, hDPSCs demonstrated pro-angiogenic capability and are able to exert a positive effect in the regeneration of nerve tissue in vivo. ${ }^{24}$

Daily, many live teeth are extracted for many reasons, such as avulsion and exfoliation or during orthodontics and periodontics. These teeth are usually discarded rather than being put to use.

The infinite potential of DPSCs, their accessibility, and the possibility of cryopreservation make them a promising source for tissue regeneration ${ }^{25}$ and stem cell banks. ${ }^{26,27}$

Dental pulp stem cells can be cryopreserved, usually with DMSO (10\%-20\%), for up to two years and still maintain their high proliferation rate, multipotency, karyotype, and stem cell surface markers. ${ }^{28}$

Considering that most dental offices are not prepared to perform cryopreservation procedures, the teeth must be taken to a specialized location. In clinical practice, it is very useful to know how much time a patient would have to take his or her own extracted, avulsed, or exfoliated tooth to a tissue culture laboratory before the pulp cells become unviable.

After an avulsion or extraction, the rupture of the neurovascular bundle causes cell death, but it is not precisely known how quickly this occurs. It is very important to establish how long pulp cells are viable in order to construct a pulp cell preservation protocol.

Other studies either do not mention the length of the interval between tooth extraction and placement of the pulp into an appropriate culture medium $^{1,29}$ or they report that the transfer was immediate. ${ }^{19}$ In other instances, the extracted teeth were immediately placed into sterile, chilled vials containing collection/transport solutions and transported on ice to a laboratory. ${ }^{30}$
If dental pulp stem cells are viable for longer periods, their isolation and storage will be more feasible and accessible.

This study aimed to investigate the amount of time that teeth can be kept at room temperature outside the culture medium and still have viable pulp cells and proliferation potential.

\section{Material and methods}

\section{Cell culture}

This study was submitted to and approved by the Ethical Committee of Health Science Centre at the University of Brasília (Brazil) under the Number CAAE: 0030.0.012.000-10; CEP 035/10.

Human dental pulp was obtained from healthy extracted permanent teeth $(n=21 ; 11$ donors aged 13-36 years) from healthy individuals after obtaining informed consents. Using a random number table, the teeth were distributed into five groups $(0 \mathrm{~h}, 0.5 \mathrm{~h}$, $1 \mathrm{~h}, 2 \mathrm{~h}$, and $5 \mathrm{~h}$ ). Each sample received a random number and all tests were conducted by trained, masked observers.

The period of time between tooth extraction and pulp removal was recorded with a chronometer. In the first group, the pulp was immediately removed and immersed in the culture medium (0h).

In the other four groups, the teeth were not housed in special conditions after extraction. They were wrapped in a gauze pad and left on the surgical table, without any cleaning process, at room temperature, without any liquid medium until the time established to pulp removal. After 30 minutes $(0.5 \mathrm{~h}), 1$ hour (1h), 2 hours ( $2 \mathrm{~h}$ ), and 5 hours (5h) the pulp was removed and immersed in the culture medium.

After the defined period of time, the following procedures were performed on each sample: a longitudinal furrow was made using a flexible diamond disc (KG Sorensen, ref. 7020, Zenith Dental ApS, AgersKov, Denmark) without touching the pulp tissue, then the teeth were sectioned using a dental elevator. The pulp tissue was gently separated with a sterile dentinal excavator.

The pulp tissue was transported to the laboratory in polystyrene microtubes (Corning Incorporated, New York, USA) containing the following 
preservatives, all purchased from GIBCO $^{\mathrm{TM}}$, Grand Island, New York, USA: Dulbecco's Modified Eagle's Medium supplemented with $20 \%$ foetal bovine serum, sodium salt, streptomycin sulphate, and amphotericin B as Fungizone ${ }^{\circledR}$ Antimycotic in $0.85 \%$ saline) and antibiotic/antimycotic $1 \%$ (GIBCO-BRL $[10,000$ units of penicillin-base; $10,000 \mu \mathrm{g}$ of streptomycin-base; and $25 \mu \mathrm{g}$ of amphotericin $\mathrm{B} / \mathrm{ml}$ utilizing penicillin $\mathrm{G}]$.

Pulp cell cultures were established by explant culture outgrowth in 6-well plates. The cells were cultured in the same medium at $37^{\circ} \mathrm{C}$ in a humidified $5 \% \mathrm{CO}_{2}$ atmosphere. The culture media were changed every three days. After one passage, when the cultures were confluent, the cells were frozen at $-80^{\circ} \mathrm{C}$ and, after one day, they were transferred to liquid nitrogen $\left(-196^{\circ} \mathrm{C}\right)$. The cryopreservation medium was $5 \%$ DMSO in foetal bovine serum.

One week before testing, all cells were thawed at $37^{\circ} \mathrm{C}$ and then re-suspended in culture medium on the same day. They were pelleted at 1,200 rpm for 10 minutes, the supernatant was removed, and fresh medium was added to the tube. The cells were re-suspended and moved to culture flasks.

\section{Morphological analysis}

For morphological analysis by light microscopy, $10^{4}$ cells of each sample were moved to each well of 24-well plates. After 48 hours, they were analysed in an inverted microscope (Zeiss, Germany, Axiovert 100) and digitally photographed (Zeiss, Germany, AxioCam MRC). After that, the cells were fixed for 15 minutes with $4 \%$ paraformaldehyde, stained with Giemsa ( $4 \%$ in methanol) for 10 minutes, and analysed again under the same microscope.

\section{Cell proliferation}

In order to test whether or not the delay in the acquisition of the sample would affect cell viability, cell proliferation was inferred by MTT assay (3-(4,5-dimethyl)-2,5-diphenyl tetrazolium bromide) and assessed by counting the cells using a haemocytometer. To perform each test, $10^{3}$ cells of each sample were passed, in triplicate, to each well of eight 96-well plates containing $200 \mu \mathrm{l}$ of regular medium. After 24, 48, 72, and 96 hours, two plates were analysed, one using the MTT assay and the other by counting the cells using a haemocytometer.

For the MTT assay, the storage medium was replaced by a fresh one containing $100 \mathrm{mg} / \mathrm{ml}$ MTT (Invitrogen, Waltham, MA, USA) and the plates were incubated for three hours at $37^{\circ} \mathrm{C}$ in a humidified $5 \% \mathrm{CO}_{2}$ atmosphere. The medium was then removed and the cells were treated with $200 \mu \mathrm{l}$ of DMSO (Mallinckrodt chemicals, New Jersey, USA) for 30 minutes. The optical density of the cell lysate was measured at $595 \mathrm{~nm}$ using a microtiter plate reader (SpectraMax M2, Molecular Devices, Sunnyvale, California, USA). The relative cell viability was calculated as a percentage of the first analysed samples (24h).

After the pre-defined periods of time, the cells were detached from the plate using trypsin-EDTA solution (GIBCO-BRL). The cell suspensions were mixed with $10 \mu$ lof $0.4 \%$ trypan blue (GIBCO-BRL) at a 1:1 ratio and living cells (not stained) were counted manually using a haemocytometer. The relative cell viability was calculated as a percentage of the first analysed samples (24h).

\section{Statistical analysis}

The intraclass correlation coefficient (ICC) test was performed to analyse repeatability and to examine whether there were variations intrinsic to the experimental system. All the ICC values above 0.7 are considered good repeatability and all the data used were higher than this parameter.

The data was statistically normalized based on the first day of culture for each experimental group. The effects of time from dental extraction and pulp culture on cell proliferation were measured by MTT and cell counting. For this, we performed a two-way ANOVA with Bonferroni post-hoc test. The level of significance was $5 \%$.

\section{Results}

\section{Cell culture}

Regardless of the time between the tooth extraction and the pulp removal and immersion into the culture media, the establishment of the culture was similar in all groups. The migration of the cells from the 
tissue fragment to the plate occurred around the tenth day. Adherent cells continued to proliferate, and confluent monolayers were formed.

\section{Morphological analysis}

The primary cultures of all experimental groups were very homogeneous at the morphological level and proliferated with a well-spread attached morphology. They had a star- or spindle-shaped appearance and polygonal contours with cytoplasmic extensions, displaying a fibroblast-like morphology. The cytoplasm had a relatively homogeneous aspect and cytoplasmic projections bound one cell to another. The nucleus was spherical or ovoid, with fine and slightly granular chromatin. One or more nucleoli was evident. The cells exhibited longer and thinner shapes in confluent culture. The cells were resistant and presented proliferation even when the culture was confluent.

The morphology of thawed cells was identical to that observed in fresh ones (Figures 1 and 2).

\section{Cell proliferation}

All groups had excellent proliferation rates. Delaying the removal of pulp tissue up to five hours did not impair cell proliferation.

On MTT evaluation after 72 hours, cell proliferation only decreased in the $1 \mathrm{~h}$ group when compared with other groups. After 96 hours, the cell proliferation decreased in the $0.5 \mathrm{~h}$ and $1 \mathrm{~h}$ groups, while it was increased in the $5 \mathrm{~h}$ group as compared to the control group.

The viable cells were counted and the growth curve was charted. All the groups were viable and proliferated well. After 48 hours, the cell proliferation decreased only in the $1 \mathrm{~h}$ group as compared to the $0 \mathrm{~h}$ group. The $2 \mathrm{~h}$ and $5 \mathrm{~h}$ groups appeared to increase the number of viable cells, but the difference was not statistically significant. After 72 hours, the number of cells in the $2 \mathrm{~h}$ and $5 \mathrm{~h}$ groups decreased as compared to $0 \mathrm{~h}$. The $5 \mathrm{~h}$ group showed little growth after 96 hours when compared with other groups.

Comparing the proliferation of permanent dental pulp cells obtained by the outgrowth method showed that all the groups demonstrated viability. A delay of up to five hours in removing the pulp tissue in order to establish the culture did not appear to damage cell proliferation.

\section{Discussion}

To date, dentistry has been conservative and the need of transferring the scientific models of regenerative dentistry into clinical practice is becoming a necessity ${ }^{31}$.

A delay in processing the pulp after tooth extraction does not appear to influence cell viability or cell count.

Considering the potential of dental pulp in tissues regeneration ${ }^{32,33}$, it is necessary to increase scientific knowledge of the cells' behaviour.

Studies indicate that DPSC isolation is feasible for at least five days after tooth extraction if the extracted teeth are stored at $4^{\circ} \mathrm{C}$ in a variety of collection/transport media ${ }^{30}$. The present study

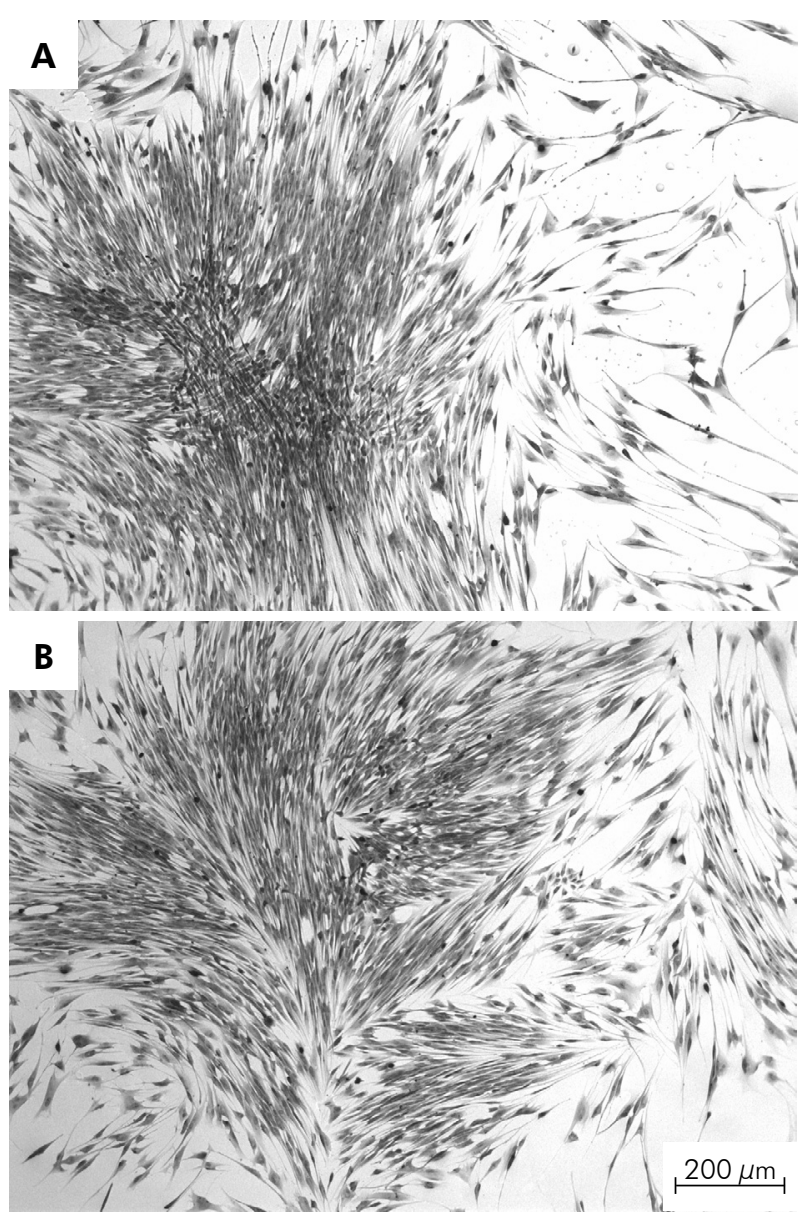

Figure 1. Illustrative phase micrographs of dental pulp cells presenting colony-forming activity stained with Giemsa. A) immediate culture; B) cultivation delay of 5 hours from the extraction. 
was designed to assess whether a delay of up to five hours in the establishment of a dental pulp cell culture would harm cell viability. The expectation was that there would be a great rate of cell death after only a few minutes because other studies describe that, after tooth extraction, the pulp cells were immediately immersed in culture medium., ${ }^{1,6,734,35} \mathrm{In}$ this study, however, the pulp cells survived at least five hours without the blood supply coming from the neurovascular bundle and at standard room temperature and atmospheric pressure. The same cell morphology appeared in all groups (Figures 1 and 2). Moreover, cryopreservation maintained the phenotype described in other studies. ${ }^{30}$

Cell adherence, migration, and proliferation occurred in all groups.

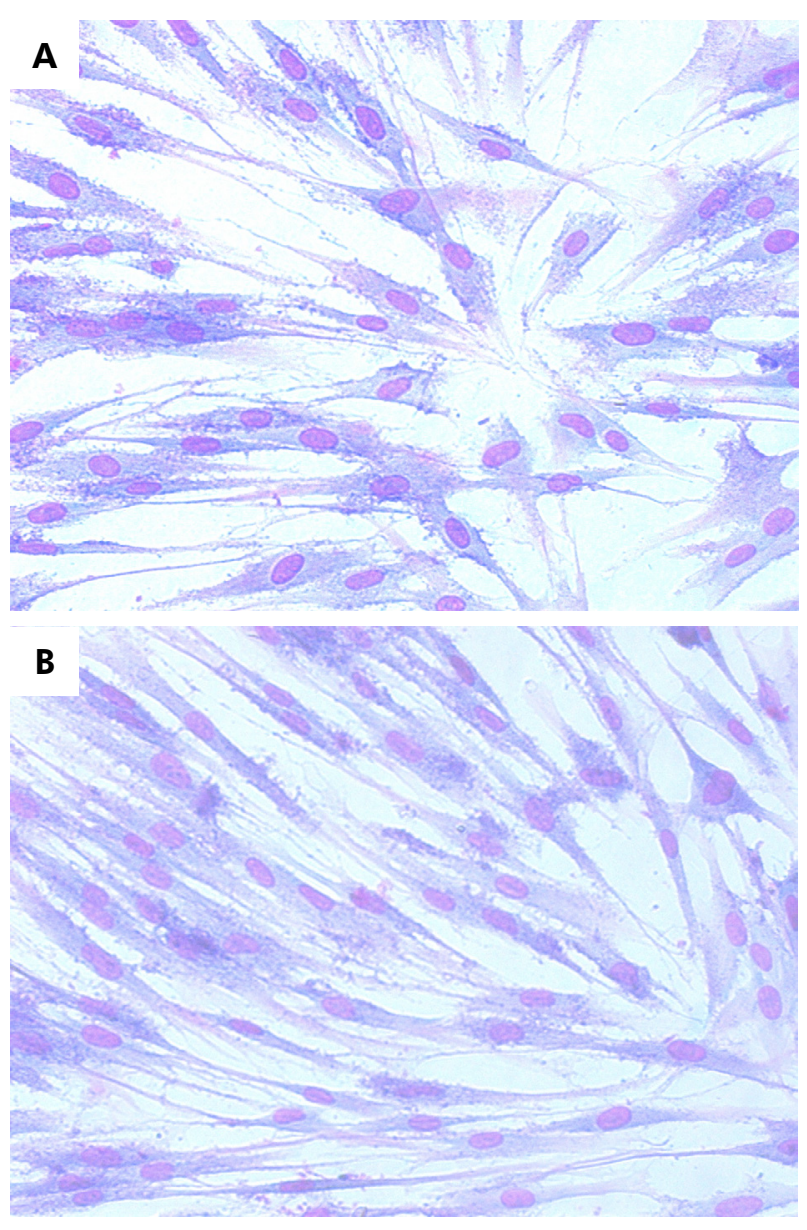

Figure 2. Illustrative phase micrographs of dental pulp cells stained with Giemsa. A) immediate culture; B) cultivation delay of 5 hours from the extraction.
MTT assay and cell counting methods were used to measure cell proliferation and viability. The similarity between the results confirms that all groups had normal proliferation and behaviour through four days. On the fourth day, all groups had at least doubled in cell number (Figures 3 and 4).

The results of this study challenge the traditional view that pulp cells will die after only a few minutes without a media culture.

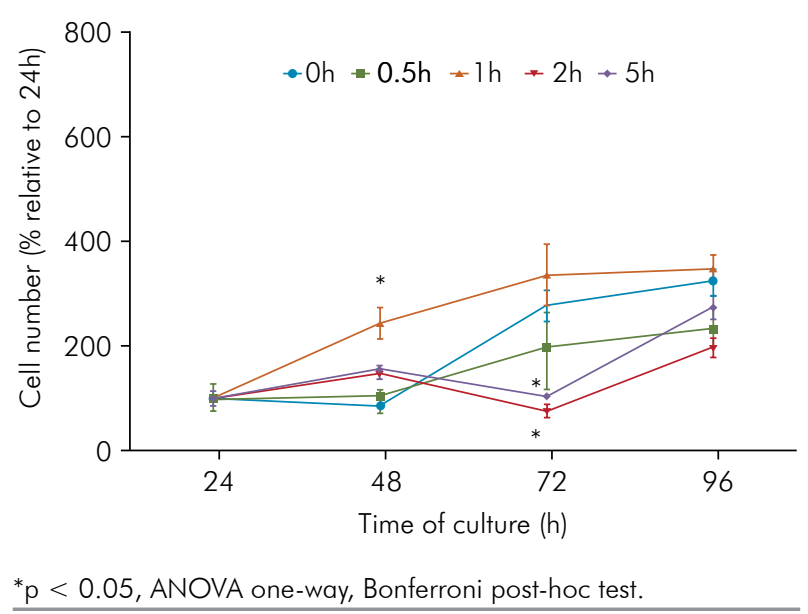

Figure 3. Comparison of cell viability among different times of pulp extraction and different times of cell culture. Data were normalized with the first day of cell culture (24 h) and expressed as mean \pm standard error of two independent experiments performed in triplicates.

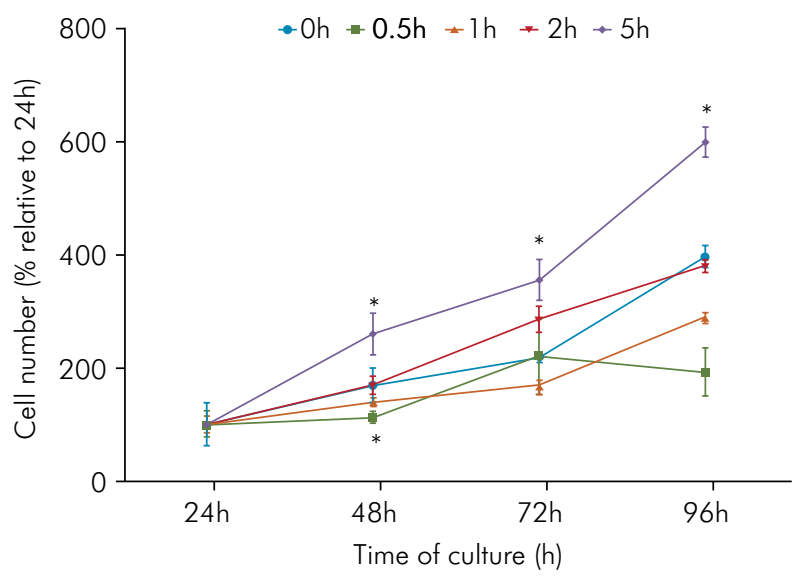

Figure 4. Effects of time between the tooth extraction and pulp removal and immersion into the culture media on the cell count. Data were normalized with the first day of cell culture $(24 \mathrm{~h})$ and expressed as mean \pm standard error of two independent experiments performed in triplicates. Different letters indicate statistical difference ( $p<0,005$, ANOVA two-way, Bonferroni post-hoc test) 
The proliferation of the cells was estimated by evaluating metabolic activity. All the groups were viable and proliferated well.

Human dental pulp tissue resides in a low-oxygen environment. This might explain the long survival of dental pulp cells after extraction. The ambient hypoxia might be suitable for the establishment and maintenance of hDPC lines. ${ }^{36}$

It was suggested that DPSCs and human deciduous pulpal fibroblasts are capable of organizing a rapid response to experimentally-induced changes in oxygen tension. They can induce complex and cell type-specific pro-angiogenic responses. ${ }^{35}$

Hypoxia seemed to decrease the DNA damage from oxidation and amplified the numbers of progenitor cells from human dental pulp. However, it is important to determine whether DPCs react differently to signalling molecules, which might change their differentiation potential. ${ }^{37}$

Hypoxia suppressed the osteo/odontogenic differentiation of hDPCs in vitro and increased the number of cells expressing STRO-1, an early mesenchymal stem cell marker. ${ }^{36}$

In other studies, the sterilization of teeth to prevent contamination was the primary obstacle to successfully establishing DPSC cultures. Although teeth were externally sterilized before being processed, some cultures became contaminated. ${ }^{30}$

In this study, the teeth were not sterilized prior to processing. The working hypothesis was that viable DPSC cultures could not beestablished for a few minutes post-extraction because of contamination. However, no cultures were lost due to bacterial contamination. If these results are generally applicable, dentists could easily help labs collect dental pulp without changing their routines. After performing the extraction, the alveolus is usually cleaned, the suture is placed, and the patient is given postoperative instructions. The pulp could easily be collected after these procedures, instead of interrupting the normal workflow to prepare the pulp.

If no one at the dentist's office is capable of preparing the tooth, the pulp could be collected at the tissue culture lab, because there would still be time after the tooth was extracted to be delivered.

Cell viability more than five hours post-extraction deserves to be better understood. Subsequent studies are needed to explain, for instance, whether the proliferation observed in this study was healthy or merely an initial sign of cell transformation. Moreover, it is recommended that further studies perform a comparative characterization of each cell population isolated after different periods of time from teeth extraction.

\section{Conclusion}

The results of this study showed that a delay of up to five hours between removing dental pulp tissue and establishing the culture did not impair cell proliferation. Furthermore, five hours might be not be the upper limit for dental pulp stem cell cultivation, so longer times need to be tested.

\section{References}

1. Gronthos S, Mankani M, Brahim J, Robey PG, Shi S. Postnatal human dental pulp stem cells (DPSCs) in vitro and in vivo. Proc Natl Acad Sci USA. 2000 Dec;97(25):13625-30. https://doi.org/10.1073/pnas.240309797

2. Alraies A, Alaidaroos NY, Waddington RJ, Moseley $R$, Sloan AJ. Variation in human dental pulp stem cell ageing profiles reflect contrasting proliferative and regenerative capabilities. BMC Cell Biol. 2017 Feb;18(1):12. https://doi.org/10.1186/s12860-017-0128-x

3. Wadman M. Temporary reprieve for stem cells. Nature. 2010 Sep;467(7313):258-9. https://doi.org/10.1038/467258a
4. Park YJ, Cha S, Park YS. Regenerative applications using tooth derived stem cells in other than tooth regeneration: a literature review. Stem Cells Int. 2016;2016:9305986. https://doi.org/10.1155/2016/9305986

5. Liu H, Li W, Shi S, Habelitz S, Gao C, Denbesten P. MEPE is downregulated as dental pulp stem cells differentiate. Arch Oral Biol. 2005 Nov;50(11):923-8. https://doi.org/10.1016/i.archoralbio.2005.03.003

6. Demarco FF, Casagrande L, Zhang Z, Dong Z, Tarquinio SB, Zeitlin $\mathrm{BD}$ et al. Effects of morphogen and scaffold porogen on the differentiation of dental pulp stem cells. J Endod. 2010 Nov;36(11):1805-11. https://doi.org/10.1016/i.joen.2010.08.031 
7. Miura M, Gronthos S, Zhao M, Lu B, Fisher LW, Robey PG et al. SHED: stem cells from human exfoliated deciduous teeth. Proc Natl Acad Sci USA. 2003 May;100(10):5807-12. https://doi.org/10.1073/pnas.0937635100

8. Govindasamy V, Abdullah AN, Ronald VS, Musa S, Ab Aziz ZA, Zain RB et al. Inherent differential propensity of dental pulp stem cells derived from human deciduous and permanent teeth. J Endod. 2010 Sep;36(9):1504-15. https://doi.org/10.1016/i.joen.2010.05.006

9. Ishkitiev N, Yaegaki K, Calenic B, Nakahara T, Ishikawa H, Mitiev $\vee$ et al. Deciduous and permanent dental pulp mesenchymal cells acquire hepatic morphologic and functional features in vitro. J Endod. 2010 Mar;36(3):469-74. https://doi.org/10.1016/i.joen.2009.12.022

10. Yu JH, Shi JN, Deng ZH, Zhuang H, Nie X, Wang RN et al. Cell pellets from dental papillae can reexhibit dental morphogenesis and dentinogenesis. Biochem Biophys Res Commun. 2006 Jul;346(1):116-24. https://doi.org/10.1016/i.bbrc.2006.05.096

11. Sonoyama W, Liu Y, Fang D, Yamaza T, Sei BM, Zhang C et al. Mesenchymal stem cell-mediated functional tooth regeneration in swine. PLoS One. 2006 Dec;1:e79. https://doi.org/10.1371/journal.pone.0000079

12. Nakao K, Morita R, Saji Y, Ishida K, Tomita Y, Ogawa M et al. The development of a bioengineered organ germ method. Nat Methods. 2007 Mar;4(3):227-30. https://doi.org/10.1038/nmeth1012

13. Cavalcanti BN, Zeitlin BD, Nör JE. A hydrogel scaffold that maintains viability and supports differentiation of dental pulp stem cells. Dent Mater. 2013 Jan;29(1):97-102. https://doi.org/10.1016/i.dental.2012.08.002PMID:22901827

14. Nakamura H, Saruwatari L, Aita H, Takeuchi K, Ogawa T. Molecular and biomechanical characterization of mineralized tissue by dental pulp cells on titanium. J Dent Res. 2005 Jun;84(6):515-20. https://doi.org/10.1177/154405910508400606

15. Otaki S, Ueshima S, Shiraishi K, Sugiyama K, Hamada S, Yorimoto $\mathrm{M}$ et al. Mesenchymal progenitor cells in adult human dental pulp and their ability to form bone when transplanted into immunocompromised mice. Cell Biol Int. 2007 Oct;31(10):1191-7. https://doi.org/10.1016/i.cellbi.2007.04.001

16. De Mendonça Costa A, Bueno DF, Martins MT, Kerkis I, Kerkis A, Fanganiello RD et al. Reconstruction of large cranial defects in nonimmunosuppressed experimental design with human dental pulp stem cells. J Craniofac Surg. 2008 Jan;19(1):204-10. https://doi.org/10.1097/scs.0b013e31815c8a54 PMID:18216690

17. Reynolds AJ, Jahoda CA. Cultured human and rat tooth papilla cells induce hair follicle regeneration and fiber growth. Differentiation. 2004 Dec;72(9-10):566-75. https://doi.org/10.1111/j.1432-0436.2004.07209010.x

18. Chachques JC, Salanson-Lajos C, Lajos P, Shafy A, Alshamry A, Carpentier A. Cellular cardiomyoplasty for myocardial regeneration. Asian Cardiovasc Thorac Ann. 2005 Sep;13(3):287-96. https://doi.org/10.1177/021849230501300322

19. Gandia C, Armiñan A, García-Verdugo JM, Lledó E, Ruiz A, Miñana MD et al. Human dental pulp stem cells improve left ventricular function, induce angiogenesis, and reduce infarct size in rats with acute myocardial infarction. Stem Cells. 2008 Mar;26(3):638-45. https://doi.org/10.1634/stemcells.2007-0484

20. Kadar K, Kiraly M, Porcsalmy B, Molnar B, Racz GZ, Blazsek J et al. Differentiation potential of stem cells from human dental origin - promise for tissue engineering. J Physiol Pharmacol. 2009 Dec;60(7 Suppl 7):167-75.

21. Gomes JA, Monteiro BG, Melo GB, Smith RL, Silva MCP, Lizier NF et al. Corneal reconstruction with tissue-engineered cell sheets composed of human immature dental pulp stem cells. Invest Ophthalmol Vis Sci. 2010 Mar;51(3):1408-14. https://doi.org/10.1167/iovs.09-4029

22. Leprince JG, Zeitlin BD, Tolar M, Peters OA. Interactions between immune system and mesenchymal stem cells in dental pulp and periapical tissues. Int Endod J. 2012 Aug;45(8):689701. https://doi.org/10.1111/j.1365-2591.2012.02028.x

23. Manimaran K, Sharma R, Sankaranarayanan S, Perumal SM. Regeneration of mandibular ameloblastoma defect with the help of autologous dental pulp stem cells and buccal pad of fat stromal vascular fraction. Ann Maxillofac Surg. 2016 JanJun;6(1):97-100. https://doi.org/10.4103/2231-0746.186128

24. Sanen K, Martens W, Georgiou M, Ameloot M, Lambrichts I, Phillips J. Engineered neural tissue with Schwann cell differentiated human dental pulp stem cells: potential for peripheral nerve repair? J Tissue Eng Regen Med. 2017 Jan. https://doi.org/10.1002/term.2249

25. Estrela C, Alencar AH, Kitten GT, Vencio EF, Gava E. Mesenchymal stem cells in the dental tissues: perspectives for tissue regeneration. Braz Dent J. 2011;22(2):91-8. https://doi.org/10.1590/S0103-64402011000200001

26. Papaccio G, Graziano A, Aquino R, Graziano MF, Pirozzi G, Menditti $D$ et al. Long-term cryopreservation of dental pulp stem cells (SBP-DPSCs) and their differentiated osteoblasts: a cell source for tissue repair. J Cell Physiol. 2006 Aug;208(2), 319-25. https://doi.org/ 10.1002/icp.20667

27. Collart-Dutilleul PY, Chaubron F, De Vos J, Cuisinier FJ. Allogenic banking of dental pulp stem cells for innovative therapeutics. World J Stem Cells. 2015 Aug;7(7):1010-21. https://doi.org/10.4252/wjsc.v7.i7.1010.

28. Conde MC, Chisini LA, Grazioli G, Francia A, Carvalho RV, Alcázar JC et al. Does Cryopreservation Affect the Biological Properties of Stem Cells from Dental Tissues? A Systematic Review. Braz Dent J. 2016 Oct-Dec;27(6):633-40. https://doi.org/10.1590/0103-6440201600980

29. Batouli S, Miura M, Brahim J, Tsutsui TW, Fisher LW, Gronthos S et al. Comparison of stem-cell-mediated osteogenesis and dentinogenesis. J Dent Res. 2003 Dec;82(12):976-81. https://doi.org/10.1177/154405910308201208 
30. Perry BC, Zhou D, Wu X, Yang FC, Byers MA, Chu TM et al. Collection, cryopreservation, and characterization of human dental pulp-derived mesenchymal stem cells for banking and clinical use. Tissue Eng Part C Methods. 2008 Jun;14(2):14956. https://doi.org/10.1089/ten.tec.2008.0031

31. Monti M, Graziano A, Rizzo S et al. In vitro and in vivo differentiation of progenitor stem cells obtained after mechanical digestion of human dental pulp. J Cell. Physiol. 2017 Mar;232(3):548-55. https://doi.org/10.1002/jcp.25452

32. Potdar PD, Jethmalani YD. Human dental pulp stem cells: applications in future regenerative medicine. World J Stem Cells. 2015 Jun;7(5):839-51. https://doi.org/10.4252/wjsc.v7.i5.839

33. Saito MT, Silvério KG, Casati MZ, Sallum EA, Nociti FH Jr. Tooth-derived stem cells: update and perspectives. World J Stem Cells. 2015 Mar;7(2):399-407. https://doi.org/10.4252/wjsc.v7.i2.399
34. Cordeiro MM, Dong Z, Kaneko T, Zhang Z, Miyazawa M, Shi S et al. Dental pulp tissue engineering with stem cells from exfoliated deciduous teeth. J Endod. 2008 Aug;34(8):962-9. https://doi.org/10.1016/i.joen.2008.04.009

35. Aranha AM, Zhang Z, Neiva KG, Costa CA, Hebling J, Nör JE. Hypoxia enhances the angiogenic potential of human dental pulp cells. J Endod. 2010 Oct;36(10):1633-7. https://doi.org/10.1016/i.joen.2010.05.013

36. lida K, Takeda-Kawaguchi T, Tezuka Y, Kunisada T, Shibata T, Tezuka K. Hypoxia enhances colony formation and proliferation but inhibits differentiation of human dental pulp cells. Arch Oral Biol. 2010 Sep;55(9):648-54. https://doi.org/10.1016/i.archoralbio.2010.06.005

37. Sakdee JB, White RR, Pagonis TC, Hauschka PV. Hypoxia-amplified proliferation of human dental pulp cells. J Endod. 2009 Jun;35(6):818-23. https://doi.org/10.1016/i.joen.2009.03.001 